\title{
Phosphatidylserine IgG Antibody Unit
}

National Cancer Institute

\section{Source}

National Cancer Institute. Phosphatidylserine IgG Antibody Unit. NCI Thesaurus. Code C161497.

A unit for semiquantitative measurement of IgG autoantibodies to proteins associated with phosphatidylserine evaluated ag ainst an established reference standard. 